\title{
Correlation between Quality of Life and Gastroesophageal Reflux Disease
}

\author{
Kevin Tandarto, ${ }^{1}$ Riki Tenggara, ${ }^{2}$ Febie Chriestya, ${ }^{2}$ Mario Steffanus ${ }^{2}$ \\ ${ }^{1}$ Faculty of Medicine, Atma Jaya Catholic University of Indonesia, Jakarta, Indonesia, ${ }^{2}$ Department of Internal \\ Medicine Faculty of Medicine, Atma Jaya Catholic University of Indonesia, Jakarta, Indonesia
}

\begin{abstract}
Gastroesophageal reflux disease (GERD) is a disease characterized by the rise of stomach acid into the esophagus which leads to heartburn and regurgitation. The prevalence of adult GERD cases worldwide is 11-38.8\%. This study aimed to determine the correlation between GERD and quality of life among patients affected by this disease. This was a cross-sectional study conducted on 92 GERD patients in Atma Jaya Hospital, Jakarta, Indonesia from April 2018 to June 2018. Two questionnaires, GERD-Q and GERD-HRQL were used in this study. A validation of the Indonesian version of the GERD-HRQL questionnaire was performed prior to this study. The Mann Whitney test was used to identify the correlation between GERD and the quality of life in patients with upper gastrointestinal symptoms. This study indicated that the GERD-HRQL questionnaire showed good validity and reliability. Results showed that there was a correlation between GERD and quality of life $(\mathrm{p}=0.005)$ in patients with upper gastrointestinal symptoms. In conclusion, GERD affects the quality of life of patients affected by this disease.
\end{abstract}

Key words: GERD, GERD-Q, quality of life

\section{Korelasi antara Kualitas Hidup dan Penyakit Refluks Gastroesofagus}

\begin{abstract}
Abstrak
Gastroesophageal reflux disease (GERD) atau penyakit refluks gastroesofagus adalah penyakit yang ditandai dengan naiknya asam lambung ke kerongkongan yang menyebabkan sensasi terbakar di dada dan regurgitasi. Prevalensi kasus GERD di seluruh dunia pada orang dewasa adalah 11-38,8\%. Penelitian ini bertujuan mengetahui korelasi antara GERD dan kualitas hidup di antara pasien yang terkena penyakit ini. Penelitian dilakukan pada 92 pasien GERD di Rumah Sakit Atma Jaya, Jakarta, Indonesia dari April 2018 hingga Juni 2018. Dua kuesioner, GERD-Q dan GERD-HRQL digunakan dalam penelitian ini. Validasi kuesioner GERD-HRQL versi bahasa Indonesia dilakukan sebelum penelitian ini. Analisis uji Mann Whitney digunakan untuk mengidentifikasi korelasi antara GERD dan kualitas hidup pada pasien dengan gejala gastrointestinal bagian atas. Penelitian ini menunjukkan bahwa kuesioner GERD-HRQL memperlihatkan validitas dan reliabilitas yang baik. Hasil penelitian ini juga menunjukkan terdapat korelasi antara GERD dan kualitas hidup $(p=0,005)$ pada pasien dengan gejala gastrointestinal atas. Simpulan, GERD mempengaruhi kualitas hidup pasien yang terkena penyakit ini.
\end{abstract}

Kata kunci: GERD, GERD-Q, kualitas hidup 


\section{Introduction}

Gastroesophageal reflux disease (GERD) is a disease characterized by stomach acid rising into the esophagus, leading to symptoms such as heartburn and regurgitation. ${ }^{1}$ The global prevalence of GERD in adults is 11-38.8\% and varies between countries. The incidence of GERD in Asia continues to increase every year. For example, the prevalence of GERD in Malaysia has increased from $2.7 \%$ in 1991-1992 to $38.8 \%$ in 2004 . In Singapore, the prevalence of GERD is $10.5 \%{ }^{2}$ The prevalence of GERD in Indonesia is also quite high. According to a study conducted by Syam et al., ${ }^{3}$ the prevalence of GERD in Indonesia is $13.3 \%$.A research conducted in the Division of Gastroenterology at the Department of Internal Medicine, Faculty of Medicine, Universitas Indonesia-Dr. Cipto Mangunkusumo Hospital Jakarta reported 22 cases of esophagitis, accounting for $8 \%$ of all patients undergoing endoscopic examination due to dyspepsia indication. ${ }^{4}$

This study aimed to determine the correlation between GERD and patients' quality of life. When the correlation between GERD and GERD-HRQL is established, it will be possible to evaluate the success of GERD treatment how severe GERD affects the quality of life.

\section{Methods}

This was a cross-sectional study using the purposive sampling method on patients treated in the internal medicine ward of Atma Jaya Hospital from April 2018 to June 2018. Ninetytwo respondents were involved with $\mathrm{Z} \alpha$ of 1.64, $\mathrm{Z} \beta$ of 1.28 , minimum coefficient correlation of 0.3 , type I error of $5 \%$ and one-way hypothesis, and type II error of $10 \%$. Data collection was performed from June to July 2018. The instrument used was the gastroesophageal reflux disease-questionnaires (GERD-Q) developed by Jonas et al. to help GERD diagnosis with a cut-off point of 8 . The GERD-Q questionnaires have been tested and validated in Indonesian Language. The quality of life in GERD patients was measured using the gastroesophageal reflux disease-health-related quality of life (GERD-HRQL) questionnaire developed by Velanovich to assess the quality of life in GERD patients. According to a study conducted by Stanghellini et al., GERD-HRQL is superior to the SF-36 quality of life questionnaire. GERD patients find it easier to complete the GERD-
HRQL questionnaire because the number of questions in the GERD-HRQL questionnaire is fewer than in the SF-36 questionnaire. Around $86 \%$ percent of the patients stated that the GERD-HRQL questionnaire better reflects the symptoms they are suffering when compared to the SF-36 questionnaire. The two instruments were translated into Indonesian then filled in by respondents.

GERD-Q is a questionnaire developed by Jonas et al. to help with GERD diagnosis. This questionnaire consists of 6 questions consisting of symptoms of reflux, dyspepsia, and symptoms related to drug use. The Indonesian version of GERD-Q has been validated and a score of $\geq 8$ indicates that a person has GERD. ${ }^{5}$ GERD-HRQL is a questionnaire developed in 1997 with the aim to quantitatively assess the quality of life in GERD patients. ${ }^{6}$

The GERD-HRQL questionnaire was tested for its validity and reliability in 30 respondents who were different from the study sample. The validity test result of the GERD-HRQL questionnaire with a degree of freedom 30-2= 28 ( $\mathrm{r}$ table $=0.361$ ) showed that the GERD-HRQL questionnaire has a good validity value. The reliability test using $r$ Cronbach's alpha showed a result of 0.926 , indicating that the GERD-HRQL questionnaire is reliable. The interpretation of GERD-HRQL is not based on good and poor categories. Instead, it is presented in numbers from zero (0) as the minimum score to fifty (50) as the maximum score. The higher the GERDHRQL score is, the worse the quality of life the patients are. ${ }^{6}$

The inclusion criteria in this study including the followings: male or female patients over 18 years old, with or without symptoms of heartburn or regurgitation, GERD-Q Score of $\geq 8$, and agreed to participate in this study. The exclusion criteria were patients who consumed drugs such as PPI, H2RA, and NSAIDs; had comorbid diseases such as kidney, heart, liver, and aplastic anemia; pregnant women; and a history of previous surgeries. Data collected were then processed using SPSS version 22 for Windows with a confidence interval of $95 \%$ and $p$ was considered significant if the value was $<0.05$. The Mann Whitney test was used to identify the correlation between GERD as the independent variable and quality of life as the dependent variable in patients with upper gastrointestinal tract symptoms.

The approval for this study was obtained from the research committee of Atma Jaya Hospital Jakarta, Indonesia with the issuance of the ethical 
clearance number 02/03/KEP-FKUAJ/2018.

\section{Results}

From a total of 92 respondents in this study, the majority were $51-70$ years old $(n=60)$. More females participated in this study ( $\mathrm{n}=67,72.8 \%)$. Most respondents finished senior high school $(\mathrm{n}=33,35.9 \%)$, were housewives $(\mathrm{n}=62,67.4 \%)$, and married $(n=91,98.9 \%)$. Table presents the demographical data of the respondents.

The median GERD-Q scores of the respondents was 10 , with 17 as the highest $(n=2$, $2.2 \%)$ and 1 as the lowest ( $n=1,1.1 \%)$. For the GERD-HRQL scores, the median was 10 with 35 as the maximum score $(n=1)$ and 0 as the minimum GERD-HRQL score $(n=3)$. The average GERD-HRQL score was 12, with 40 patients had a GERD-HRQL score of $\geq 2$.

Based on the results of the Mann Whitney test, a correlation $(\mathrm{p}=0.005)$ between the GERD and quality of life in patients with upper gastrointestinal tract symptoms was established.

\section{Discussion}

Ninety-two (92) patients suffering from gastrointestinal diseases participated in this study, with female patients as the majority $(\mathrm{n}=67,72.8 \%)$. This was similar to the suggestion from Wang et al. ${ }^{7}$ in China that the majority of patients suffering from gastrointestinal disease (GERD) are female. The respondents of this study comprises of $52.2 \%$ females and $47.8 \%$ males. Anti-inflammatory actions of estrogen and esophageal epithelial resistance against refluxate are likely to be associated with sex and gender differences in GERD spectrum between men and women. ${ }^{15}$

This study also found that the majority

Table Respondent Characteristics

\begin{tabular}{|c|c|c|c|}
\hline Variable & Value & $\begin{array}{c}\text { GERD-Q Negative } \\
\text { (Scores 0-7) } \\
\text { n (\%) }\end{array}$ & $\begin{array}{c}\text { GERD-Q Positive } \\
\text { (Scores 8-18) } \\
\text { n (\%) }\end{array}$ \\
\hline \multicolumn{4}{|l|}{ Age (years) } \\
\hline $18-30$ & 2 & $0(0)$ & $2(100)$ \\
\hline $31-50$ & 20 & $6(30)$ & $14(70)$ \\
\hline $51-70$ & 60 & $16(26.7)$ & $44(73.3)$ \\
\hline$>70$ & 10 & $2(20)$ & $8(80)$ \\
\hline \multicolumn{4}{|l|}{ Sex } \\
\hline Male & $25(27.2 \%)$ & $8(32)$ & $17(68)$ \\
\hline Female & $67(72.8 \%)$ & $16(23.9)$ & $51(76.1)$ \\
\hline \multicolumn{4}{|l|}{ Marital Status } \\
\hline Not Married & $1(1.1 \%)$ & $0(0)$ & $1(100)$ \\
\hline Married & $91(98.9 \%)$ & $24(26.4)$ & $67(73.6)$ \\
\hline \multicolumn{4}{|l|}{ Educational Degree } \\
\hline None & $4(4.3 \%)$ & $1(25)$ & $3(75)$ \\
\hline Elementary & $24(26.1 \%)$ & $5(20.8)$ & $19(79.2)$ \\
\hline Junior High School & $28(30.4 \%)$ & $8(28.6)$ & $20(71.4)$ \\
\hline Senior High School & $33(35.9 \%)$ & $10(30.3)$ & $23(69.7)$ \\
\hline Diploma/bachelor & $3(3.3 \%)$ & $0(0)$ & $3(100)$ \\
\hline \multicolumn{4}{|l|}{ Job Status } \\
\hline Job & $24(26.1 \%)$ & $5(20.8)$ & $19(79.2)$ \\
\hline Housewife & $62(67.4 \%)$ & $16(25.8)$ & $46(74.2)$ \\
\hline Unemployed & $6(6.5 \%)$ & $3(50)$ & $3(50)$ \\
\hline
\end{tabular}




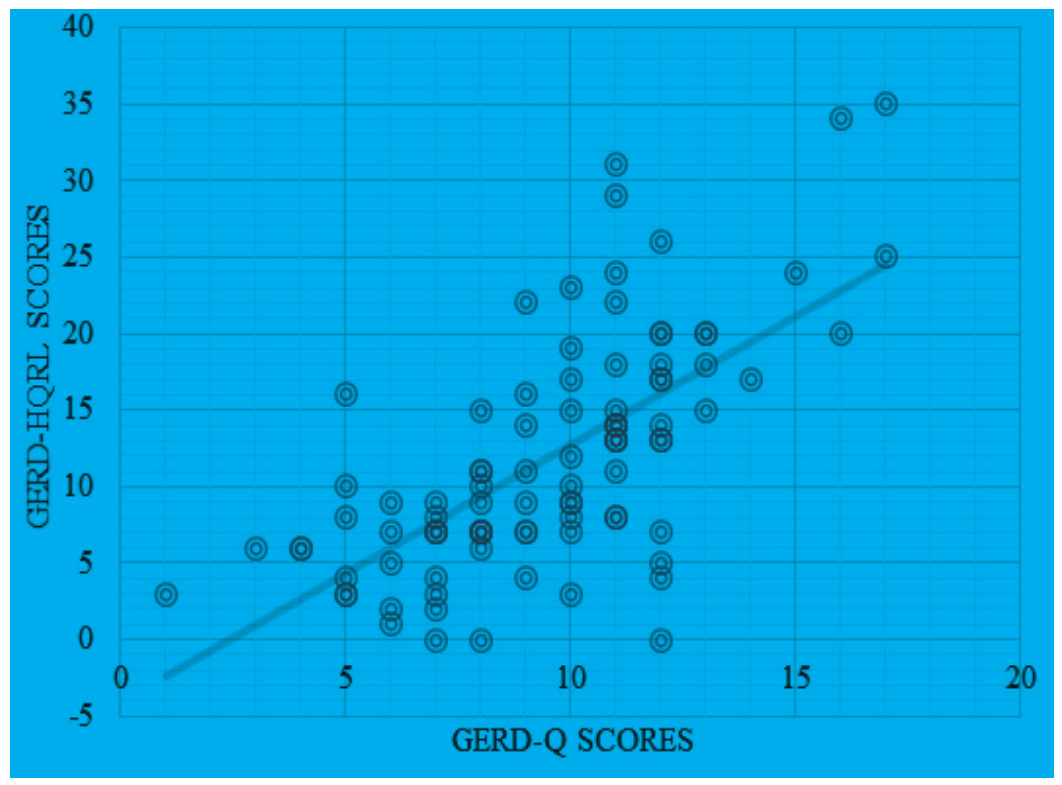

\section{Figure Correlation between Gerd-Q Score and Quality of Life in Patients of Atma Jaya Hospital, Jakarta, Indonesia}

of patients suffering from gastrointestinal tract symptoms were married $(\mathrm{n}=91,98.9 \%)$, suggesting that stress in marriage may trigger GERD. This finding is similar to the finding of Maleki et al. ${ }^{8}$ in Iran with 47 from 55 patients complaining of gastrointestinal disorders are married. The majority of patients in this study were senior high school graduates (35.9\%), which is similar to the patients studied by Maleki et al. ${ }^{8}$ with $40 \%$ of patients having symptoms of GERD are people with low education. The higher the education of a person is, the less frequent that person has a gastrointestinal tract disease. This may be due to the fact that people with higher education tend to seek early treatment from the doctor for their symptoms and tend to maintain a healthy lifestyle.

Most of the patients in this study were housewives ( $n=62,67.4 \%)$, which is partially in line with the finding by Maleki et al. ${ }^{8}$ stating that most patients with gastrointestinal disease are housewives ( $\mathrm{n}=30,33.3 \%)$ and unemployed $(n=26,28.9 \%)$. This study only identified 6 unemployed patients $(6.5 \%)$ among the respondents.

This study aimed to assess the correlation between GERD and quality of life in patients with upper gastrointestinal tract symptoms. The GERD-HRQL questionnaire was used to assess the quality of life of patients with gastrointestinal tract symptoms. Research on the quality of life in GERD patients has been performed globally but not many in Indonesia. Studies worldwide seem to agree that GERD reduces a person's quality of life, including several studies in Western countries. $^{7}$

This present study revealed a correlation between GERD-Q and quality of life among patients treated in Atma Jaya Hospital, Jakarta, Indonesia, with a correlation p-value of 0.005 which means there is a correlation between GERD and quality of life. This is similar to the study by Wang et al. ${ }^{7}$ in China, stating that patients with symptoms of GERD had decreased quality of life.This decrease in the quality of life is identified in several social, function, mental health, bodily pain, and general health domains. The GERD-HRQL scores also increase in patients whose GERD-Q scores are high, implying a deterioration in quality of life. In other studies, GERD is also found to be associated with the quality of sleep. ${ }^{7}$

Jang et al. ${ }^{12}$ in their study found that GERD relates to stress, anxiety, and depression. In a Japan study, it was discovered that in addition to the decrease in the quality of life, GERD is also associated with mental conditions.Research on patients with GERD symptoms in Germany, Austria, Switzerland, Sweden, and North America found that a correlation with the quality 
of life. In Norway, the population suffering from GERD is linked to anxiety and depression, which is similar to the finding among the Swedish population, with an association between GERD and psychological disorders. ${ }^{7-9}$

Various studies have also been performed in Asia to understand the correlation between GERD and quality of life. Yang et al. in China showed that GERD patients had decreased quality of life and that GERD is associated with stress, depression, and anxiety. ${ }^{14}$

Thereareseveraltheoriesonhowpsychological disorders can increase the occurrence of reflux, which is one of the symptoms of GERD. The first theory suggests that stress and anxiety coexist with reflux that both conditions may aggravate the occurrence of reflux. The second theory proposes that reflux is more severe in patients with mental disorders. ${ }^{7}$ Acute stressors increase resting lower-esophageal sphincter pressure and impair sphincter relaxation, thus delaying acid clearance from the esophagus. Stress can produce altered GI motility and symptoms. Therefore, stress could induce objective reflux of gastric contents and eventually result in reflux esophagitis, regardless of the presence of symptoms. Furthermore, stress is believed to induce reflux esophagitis by increasing the esophageal mucosal permeability. ${ }^{16}$

Research conducted by Supriyanti et al. ${ }^{9}$ in Indonesia showed that GERD is associated with financial stress. GERD-related stress factors could reduce a person's quality of life. GERD could interfere with patients' daily activities and may reduce work productivity, leading to less income.

Many factors influence the decreasing quality of life in GERD patients, as reflected in the findings of this study. Gender, age, education and knowledge, personality, culture, and beliefs are some of the factors that play a role in decreasing the quality of life in GERD patients. ${ }^{7}$ In a study conducted by Kaji et al. ${ }^{11}$ in Japan, GERD is shown to affect the quality of life in the Japanese general population. In Guangzhou, China, the quality of life of GERD patients is not found to decrease significantly. ${ }^{7}$ A study conducted by Jang et al. ${ }^{12}$ stated that the GERD risk is higher for the following occupational stress subcategories: job demand, lack of rewards, interpersonal conflict, and occupational climate.These domains could be influenced by different socio-cultural conditions between populations. Age, family support, relationships with family members, low-paid jobs, different diets between countries, and lifestyles are some of the causes affecting the decreasing quality of life in GERD patients. ${ }^{13}$

This study has several limitations, including the timing of the interviews with a very limited number of respondents. Furthermore, a decrease in the quality of life of patients could be caused by undiagnosed anxiety and depression. The fact that the respondents only consist of patients from the internal medicine ward of Atma Jaya Hospital may bring concerns that they may not represent all patients of the Atma Jaya Hospital. Endoscopy was not conducted in this study, making the result of this study applicable for the primary health service, where the correlation of the GERD and the quality of life can be assessed by using GERD-Q and GERD-HRQL questionnaires to evaluate the success of the treatment and to understand how much GERD affects the quality of life of the patient.

In conclusion, there is a correlation between GERD and the quality of life of patients with upper gastrointestinal tract symptoms. Thus, GERD affects the quality of life of the patient.

\section{References}

1. Katz PO, Gerson LB, Vela MF. Guidelines for the diagnosis and management of gastroesophageal reflux disease. Am J Gastroenterol 2013;108(1);108-308.

2. Bai Y, Du Y, Zou D, Jin Z, Zhan X, Li Z-S, et al. Gastroesophageal reflux disease questionnaire (gerdQ) in real-world practice: a national multicenter survey on 8065 patients. J Gastroenterol Hepatol. 2013;28(4):626-31.

3. Syam AF, Putri L, Rahardja C, Utari AP, Syam AF. Prevalence of gastroesophageal reflux disease and its risk factors in rural area. Indones J Gastroenterol Hepatol Dig Endosc 2017:18(1):9-14.

4. Naomi DA. Obesity as Risk factor of gastroesophageal reflux disease. J Majority. 2014:3(7):22-6.

5. Siregar GA, Halim S, Sitepu RR. Comparison of endoscopic findings with gastroesophageal reflux disease questionnaires (GERDQ) and reflux disease questionnaire (RDQ) for gastroesophageal reflux disease in Medan. Indones J Gastroenterol Hepatol Dig Endosc 2015;16(3):143-7.

6. Doulami G, Triantafyllou S, Natoudi M, Albanopoulos K, Leandros E, Zografos G, et al. GERD-related questionnaires and obese population: can they really reflect the severity of the disease and the impact of 
GERD on Quality of Patients' Life?. Obes Surg. 2015;25(10):1882-5.

7. Wang R, Zou D, Ma X, Zhao Y, Yan X, Yan H, et al. Impact of gastroesophageal reflux disease on daily life: the Systematic Investigation of Gastrointestinal Diseases in China (SILC) epidemiological study. Health Qual Life Outcomes 2010;8:128.

8. Maleki I, Masoudzadeh A, Khalilian A, Daheshpour E. Quality of life in patients with gastroesophageal reflux disease in an Iranian population. Gastroenterol Hepatol Bed Bench. 2013;6(2):96-100.

9. Supriyatin J. Gastroesophageal reflux diseases pada ibu rumah tangga dewasa muda dengan stressor financial keluarga. J Medula. 2013;1(2):89-95.

10. Suzuki H, Matsuzaki J, Masaoka T, Inadomi JM. Greater loss of productivity among Japanese workers with gastro-esophageal reflux disease (GERD) symptoms that persist vs resolve on medical therapy. Neurogastroenterol Motil. 2014;26(6):76471.

11. Kaji M, Fujiwara Y, Shiba M, Kohata Y, Yamagami $\mathrm{H}$, Tanigawa T, et al. Prevalence of overlaps between GERD, FD and IBS and impact on health-related quality of life. J Gastroenterol Hepatol. 2010;25(6):1151-6.

12. Jang SH, Ryu HS, Choi SC, Lee SY. Psychological factors influence the gastroesophageal reflux disease (GERD) and their effect on quality of life among firefighters in South Korea. Int J Occup Environ Health. 2016;22(4):315-20.

13. Lee SW, Chang CM, Chang CS, Kao AW, Chou MC. Comparison of presentation and impact on quality of life of gastroesophageal reflux disease between young and old adults in a Chinese population. World J Gastroenterol. 2011;17(41):4614-8.

14. Yang XJ, Jiang HM, Hou XH, Song J. Anxiety and depression in patients with gastroesophageal reflux disease and their effect on quality of life. World J Gastroenterol. 2015;21(14):4302-9.

15. Kim YS, Kim N, Kim GH. Sex and gender differences in gastroesophageal reflux disease. J Neurogastroenterol Motil. 2016; 22(4):575-88.

16. Song EM, Jung HK, Jung JM. The association between reflux esophagitis and psychosocial stress. Dig Dis Sci. 2013;58(2):471-7.

17. Zavala-Gonzáles MA, Azamar-Jacome AA, Meixueiro-Daza A, Ramos A, Reyes-Huerta JJ, Roesch-Dietlen F, et al. Validation and diagnostic usefulness of gastroesophageal reflux disease questionnaire in a primary care level in Mexico. J Neurogastroenterol Motil. 2014;20(4):475-82. 